\title{
$\begin{array}{lllllllllllllllll}\mathbf{R} & \mathbf{O} & \mathbf{Z} & \mathbf{P} & \mathbf{R} & \mathbf{A} & \mathbf{W} & \mathbf{Y} & \mathbf{I} & \mathbf{A} & \mathbf{R} & \mathbf{T} & \mathbf{Y} & \mathbf{K} & \mathbf{U} & \mathbf{L} & \mathbf{Y}\end{array}$
}

Prawo Kanoniczne 58 (2015) nr 1

KS. WOJCIECH GÓRALSKI

Wydział Prawa Kanonicznego

Uniwersytetu Kardynała Stefana Wyszyńskiego w Warszawie

\section{PROBLEM WYSTĄPIENIA Z KOŚCIOŁA KATOLICKIEGO W REPUBLICE FEDERALNEJ NIEMIEC}

Treść: Wprowadzenie. - 1. Wystąpienie z Kościoła katolickiego w świetle ustawodawstwa RFN. - 2. Wyjaśnienie Konferencji Episkopatu RFN z 24.04.2006 r. w sprawie wystąpienia z Kościoła katolickiego. - 3. Dekret generalny Konferencji Episkopatu RFN z 20.09.2012 r. w sprawie wystąpienia z Kościoła katolickiego. - 4. Pismo pastoralne (załącznik do Dekretu generalnego). - Zakończenie.

\section{Wprowadzenie}

Znaczącym novum KPK z 1983 roku w dziedzinie małżeństwa była dyspozycja, w myśl której wierny, który „formalnym aktem” odstąpił od Kościoła katolickiego („actu formali ab ea [Ecclesia catholica W.G.] defecerit"), nie jest związany przeszkodą różności religii (kan. 1086 \$1 KPK), obowiązkiem zachowania formy kanonicznej zawarcia małżeństwa (kan. $1117 \mathrm{KPK}$ ) oraz wymogiem uzyskania zgody ordynariusza miejsca na zawarcie małżeństwa mieszanego (kan. 1124 KPK). Tego rodzaju modyfikacja uchylała tym samym obowiązującą dotąd zasadę semel catholicus, semper catholicus i oznaczała wprowadzenie wyjątku od kan. $11 \mathrm{KPK}$, który stanowi, iż ustawom czysto 
kościelnym podlegają ochrzczeni w Kościele katolickim lub do niego przyjęci ${ }^{1}$.

Wprowadzony w odniesieniu do wymienionych kanonów zwrot: „formalny akt odstąpienia od Kościoła katolickiego" nastręczał w wielu środowiskach uzasadnione wątpliwości interpretacyjne, zarówno co do istoty teologicznej, jak i samego aspektu kanonicznego owego aktu. W szczególności chodziło o rozumienie przymiotnika „formalny”, co miało zastosowanie przede wszystkim w odniesieniu do formy kanonicznej. Nic też dziwnego, że liczni biskupi, wikariusze sądowi oraz inne osoby zajmujące się stosowaniem prawa kanonicznego zaczęli się zwracać o wyjaśnienie tego pojęcia do Papieskiej Rady do Spraw Tekstów Prawnych ${ }^{2}$. Co więcej, pojawiłyby się także głosy postulujące wręcz zniesienie owej klauzuli ${ }^{3}$.

\footnotetext{
${ }^{1}$ Wprowadzając tak daleko idącą zmianę ustawodawca zamierzał w rzeczywistości zagwarantować ważność małżeństw osób, które formalnym aktem odstąpiły od Kościoła katolickiego, a dokonując takiego aktu nie utraciły ius connubii; wyjęcie ich spod obowiązku zachowania formy kanonicznej miało ułatwić wykonywanie tego prawa.

${ }^{2}$ M. A. Ortiz, Abbandono della Chiesa e forma del matrimonio, w: La giurisdizione della Chiesa sul matrimonio e sulla famiglia, red. J. Carreras, Milano 1998, s. 181-214; V. DE PAOLIs, Alcune annotazioni circa la formula , actu formali ab Ecclesia Catholica deficere”, Periodica 84(1995), s. 579-608; P. Moneta, I soggetti tenuti ad osservare la forma canonica: il canone 1117, w: La giurisdizione della Chiesa sul matrimonio e sulla famiglia, s. 149-179; P. ETzI, Considerazioni sull',, actus formalis defectionis" in cui nei cann. $1086 \S 1,1117,1124$ del C.I.C., w: La giurisdizione della Chiesa sul matrimonio e sulla famiglia, s. 215-250; W. GóRALSKI, Formalny akt odstąpienia od Kościoła katolickiego w świetle Listu okólnego Papieskiej Rady do Spraw Tekstów Prawnych z dnia 13 marca 2006 roku, Prawo Kanoniczne 51(2008) nr 3-4, s. 15-17.

${ }^{3}$ P. López Gallo, Formal defection from the Catholic Church, Monitor Ecclesiasticus 123(1998), s. 620-646; S. Villeggiante, Dispensabilità della forma di celebrazione del matrimonio e problematica inerente all'abbandono della fede con atto formale, w: Matrimoni misti, Città del Vaticano 1998, s. 159-173; Zdecydowanym krytykiem wprowadzenia do nowego KPK owej klauzuli stanowiącej wyjątek od kan. 11 był W. Aymans, który od 1992 roku domagał się jej zniesienia, a tym samym powrotu do zasady semel catholicus, semper catholicus, która powinna mieć zastosowanie także w prawie małżeńskim. Zob. www.internetsv.info/Actus.html; P. V.
} 
W odpowiedzi na tego rodzaju prośby Papieska Rada, po konsultacji z konferencjami biskupów i przedłożeniu ich stanowiska zebraniu plenarnemu tegoż organu z 4 czerwca 1999 roku, postanowiła jednomyślnie zwrócić się do Jana Pawła II o zniesienie klauzuli. Decyzję tę papież zatwierdził 3 lipca 1999 roku, polecając przygotowanie odpowiedniego tekstu ustawodawczego ${ }^{4}$.

W międzyczasie jednak wymieniona dykasteria kurialna była zmuszona wypowiedzieć się w sprawie interpretacji zwrotu „odejście od Kościoła formalnym aktem”, czego dokonała w Liście okólnym z 13 marca 2006 roku, przyjmując interpretację restrykcyjną ${ }^{5}$. Stwierdzono w nim - prawdopodobnie w celu położenia kresu interpretacji, która sytuowała w obrębie kan. 1117 KPK także wystąpienie z Kościoła w Niemczech - że akt formalny w rozumieniu wymienionego kanonu, dotyczy jedynie aktu sformalizowanego przed władzą kościelną, i że w ten sposób będzie on mógł zagwarantować znaczenie teologiczne woli wystąpienia z Kościoła ${ }^{6}$. Czymś szczególnie znaczącym było tu zdeklarowanie, iż formalny akt odstąpienia od Kościoła katolickiego (obejmujący decyzję wewnętrzną, jej ujawnienie władzy kościelnej oraz przyjęcie jej przez tę władzę), mający wszystkie znamiona ważnego aktu prawnego, nie ma jedynie charakteru prawno-administracyjnego, lecz także wymiar teologiczny, zakłada bowiem dokonanie aktu apostazji, herezji lub schizmy. Aktu takiego nie mogło zatem stanowić zwykłe „wypisanie się” z rejestru

Aimone Braida, Breve commento al decreto generale della Conferenza Episcopale Tedesca entrato in vigore il 28.9.2012 circa l'uscita dalla Chiesa (,Kirchenaustritt”), Quaderni di Diritto e Politica Ecclesiastica 21(2013), s. 179-180.

${ }^{4}$ A. M. Ortiz, L'obbligarietà della forma canonica matrimoniale dopo il M.P. „Omnium in mentem”, Ius Ecclesiae 22(2010), s. 482.

${ }^{5}$ Litterae circulares missae omnibus Conferentiis episcopalibus (variis linguis exaratae), quoad verba "actus formalis defectionis ab Ecclesia catholica” (Cann. 1086, § 1; 1117 e 1124 CIC) et quaedam epistulae respicientes ipsarum litterarum, Communicationes 38(2006), s. 170-189.

${ }^{6} \mathrm{Na}$ temat szczegółowego omówienia postanowień Listu okólnego zob. W. GóRALSKI, Formalny akt odstąpienia od Kościoła katolickiego, s. 15-28. 
członków wspólnoty kościelnej, m.in. poprzez złożenie na ręce władz państwowych oświadczenia o nieuiszczaniu podatku kościelnego.

Jak zauważa A. M. Ortiz, doktryna upatrywała w tym dokumencie odpowiedź na problem, jaki powstał w środowisku niemieckim, gdzie odejście od Kościoła katolickiego (Kirchenaustritt) ma swoją specyficzną regulację polegającą na integralnym powiązaniu przynależności wyznaniowej do Kościoła katolickiego (lub innego związku wyznaniowego mającego status korporacji prawa publicznego) z obowiązkiem uiszczania podatku kościelnego (Kirchensteur). Wygaśnięcie bowiem tego obowiązku następuje poprzez wystąpienie z Kościoła katolickiego; jest to jedyna możliwość uwolnienia się od tej powinności (nie licząc utraty miejsca stałego zamieszkania bądź stałego pobytu). Skuteczność wygaśnięcia obowiązku podatkowego jest uwarunkowana zachowaniem przepisów odnośnych ustaw obowiązujących w poszczególnych landach. Chodziło zatem o skuteczność kościelną ewentualnej deklaracji złożonej przez katolika przed podatkowym urzędnikiem cywilnym o nieprzynależności do Kościoła katolickiego, i w konsekwencji do bycia wolnym od obowiązku płacenia tzw. podatku na kult ${ }^{7}$.

Trudności w stosowaniu klauzuli kodeksowej (w rozumieniu Listu okólnego Papieskiej Rady) o wyjęciu spod wymienionych wyżej kanonów, w szczególności kan. 1117 KPK, tych którzy formalnym aktem odstąpili od Kościoła, spowodowały uchylenie jej - trzy lata później - przez motu proprio Benedykta XVI Omnium in mentem z 26 października 2009 roku $^{8}$. Oznaczało to, że mimo odejścia od Kościoła katolickiego przez ochrzczonego w Kościele katolickim lub do niego przyjętego, obowiązują go przepisy wymienionych na wstępnie trzech kanonów KPK, a więc dotyczące przeszkody różności religii, formy kanonicznej oraz zawarcia małżeństwa mieszanego.

\footnotetext{
${ }^{7}$ A. M. Ortiz, L'obbligarietà della forma canonica, s. 483.

${ }^{8}$ Benedictus XVI, Motu proprio „Omnium in mentem” (26.10.2009), AAS 102(2010), s. 9-10.
} 
Ani wyjaśnienie podane w Liście okólnym Papieskiej Rady ds. Tekstów Prawnych ani postanowienie motu proprio Benedykta XVI nie uchyliły problemu wystąpienia z Kościoła katolickiego Niemczech.

\section{Wystąpienie z Kościoła katolickiego w świetle ustawodawstwa RFN}

Jak już wyżej wspomniano, przynależność wyznaniowa do Kościoła katolickiego w Niemczech wiąże się ściśle z obowiązkiem uiszczania podatku kościelnego, co należy postrzegać w kontekście istniejącego w tym kraju systemu relacji zachodzących między państwem i Kościołem (system ten oparty jest na trzech podstawowych zasadach: wolności religijnej, zakazie ustanawiania kościoła państwowego oraz autonomii związków wyznaniowych). Specyfikę modelu owych relacji współtworzy niewątpliwie cała sfera finansowania Kościoła katolickiego (i innych związków wyznaniowych). System tego finansowania zbudowany jest - poza dochodami z dóbr kościelnych i świadczeniami państwa na rzecz Kościoła katolickiego (i innych związków wyznaniowych) - na podatku kościelnym (Kirchensteuer); podatek ten stanowi podstawowe źródło tegoż finansowania.

Instytucja podatku kościelnego w Niemczech (pobieranego przez organy podatkowe poszczególnych landów), sięgająca swoimi korzeniami zaboru dóbr kościelnych w okresie sekularyzacji na przełomie XVIII i XIX wieku, została uprawomocniona w 1803 roku, a następnie potwierdzona konkordatem niemieckim z 1933 roku. Ma ona swoje umocowanie konstytucyjne (art. 140 Grundgezetz; 137, 1 Weimar Reichverfassung) i jest wpisana do traktatu zjednoczeniowego Niemiec z 1990 roku. Kirchensteuer polega na świadczeniu pieniężnym o charakterze przymusowym, nieodpłatnym i stałym (na cele kościelne), uiszczanym na rzecz wspólnoty kościelnej (mającej status korporacji prawa publicznego) przez wiernych do niej należących, którzy posiadają miejsce stałego zamieszkania lub stałego pobytu na obszarze obowiązywania ustawy podatkowej'; proces

\footnotetext{
${ }^{9}$ F. GiEse, Deutsches Kirchensteurrecht, Stuttgart 1910 (ed. ristampata 1965), s. 576; Por. M. KoseK, Podatek kościelny w niemieckim systemie prawnym, Płock 2004, s. 92.
} 
wymiaru podatku jest podporządkowany przepisom kodeksu postępowania administracyjnego. Chodzi zatem o kompetencję przyznaną przez państwo określonym związkom wyznaniowym w sferze publiczno-prawnej, polegającą na możliwości wprowadzenia podatku, który - choć określony mianem podatku kościelnego - jest jednak podatkiem państwowym ze wszystkimi konsekwencjami, łącznie z przymusem ściągania go. Nie jest to więc podatek regulowany prawem wewnętrznym związku wyznaniowego (jak np. podatek nałożony na podstawie kan. $1260 \mathrm{KPK}$ ).

Konstytucyjny obowiązek prawnej regulacji podatku kościelnego jest określony przez ustawodawstwa poszczególnych landów ${ }^{10}, \mathrm{z}$ reguły $\mathrm{w}$ formie ustawowej. Każdy kraj związkowy posiada własną ustawę regulującą Kirechsteuer ${ }^{11}$. Ustawodawstwo państwowe o podatku kościelnym stanowi pewne ramy dla regulacji wyznaniowych (co do rodzaju podatku i sposobu jego uiszczania, stawki oraz formy administrowania), w których to ramach musi „zmieścić się” ustawodawca kościelny ${ }^{12}$. Akty prawne związku wyznaniowego regulujące szczegółowo podatek kościelny wymagają zatwierdzenia przez kompetentny organ państwowy ${ }^{13}$.

Aktualne regulacje ustawowe o wystąpieniu z Kościoła katolickiego (czy innego związku wyznaniowego o statusie korporacji prawa publicznego), ukształtowane w poszczególnych landach w określonym kontekście historyczno-prawnym (poczynając od połowy XIX wieku) ${ }^{14}$, wynikają przede wszystkim $\mathrm{z}$ art. 4 Konstytucji Republiki Federalnej Niemiec, który gwarantuje obywatelom wolność religijną w aspekcie negatywnym (wolność ta wyraża się m.in.

\footnotetext{
${ }^{10}$ Zob. M. Kosek, Podatek kościelny, s. 96.

${ }^{11}$ Jedynie na terytorium dawnej Niemieckiej Republiki Demokratycznej podatek kościelny został wprowadzony jedną ustawą (z 31 sierpnia 1990 roku). Zob. Tamże. ${ }^{12}$ Zob. H. Marrè, Das kirchliche Besteuerungstrecht, w: Handbuch des Staatskirchenrechts der Bundesrepublik Deutschland, red. E. Friesenhahn, U. Scheuner, wyd. 2, t. 1-2, Regensburg 1994-1996, s. 1115 nn.

${ }^{13}$ Ibidem, p. 1116.

${ }^{14}$ Zob. A. Fr. Campenhausen, Staatskirchenrecht, München 1996, s. 166-167.
} 
w możliwości zmiany wyznania czy światopoglądu, a tym samym wystąpienia z określonego związku wyznaniowego) ${ }^{15}$.

Prawne wystąpienie z Kościoła katolickiego (lub innego związku wyznaniowego o statusie korporacji prawa publicznego) uwarunkowane jest osobistym złożeniem przed kompetentnym organem państwowym (Urząd Stanu Cywilnego lub Sąd Rejonowy) ustnego lub pisemnego oświadczenia, które zawiera jednoznacznie wyrażoną wolę wystąpienia z tegoż Kościoła. Tylko ten sposób wystąpienia wywołuje skutki na gruncie prawa państwowego; ustawodawca państwowy nie jest natomiast kompetentny do decydowania o tym, jakie skutki wywiera owo oświadczenie w sferze prawa Kościoła jako korporacji prawa publicznego ${ }^{16}$. Jak zauważa R. Puza, „ograniczenie to jedynie do zakresu prawnego państwowego ma także swoją konsekwencję w tym, iż organ państwowy nie jest uprawniony do przyjęcia deklaracji o Kirchenaustritt, do której byłyby dołączone wskazania odnoszące się do zakresu wewnętrznego samego Kościoła, z wystawieniem następnie zaświadczenia o dokonanym wystąpieniu z Kościoła"17.

Oświadczenie o wystąpieniu z Kościoła nabiera mocy prawnej od momentu jego złożenia. Oznacza to, że dana osoba przestaje być na gruncie prawa publicznego podmiotem jakichkolwiek uprawnień i obowiązków związanych z przynależnością do Kościoła; wyjątkiem jest obowiązek uiszczania podatku kościelnego: ustaje on wraz z upływem miesiąca następującego po złożeniu oświadczenia o wystąpieniu $\mathrm{z}$ Kościoła $^{18}$. A contrario, ograniczenie przez Kościół praw własnego

\footnotetext{
${ }^{15}$ Zob. M. Kosek, Podatek kościelny, s. 32-33 i 124-125; R. Puza, Le conseguenze civili dell'uscita dalla Chiesa in Germania e in Austria, Veritas et Jus 6(2013), s. 22-24.

${ }^{16}$ M. Kosek, Podatek kościelny, s. 126; R. Puza, Le conseguenze civili, s. 25.

${ }^{17}$ „La limitazione al solo ambito giuridico statale ha anche come conseguenza che un organo statale non è autorizzato ad accetare una dichiarazione di Kirchenaustritt cui siano state aggiunte specificazioni che si referiscano all'ambito interno della Chiesa stessa, rilasciando poi una certificazione di avvenuto Kirchenaustritt". R. PuZA, Le conseguenze civili, s. 32; A. HolleBraCH, Kirchensteuerund Kirchenbeitrag, w: Handbuch des katholischen Kirchenrechts, Regensburg 1983, s. 898.

${ }^{18}$ M. Kosek, Podatek kościelny, s. 127.
} 
członka w drodze sankcji kanonicznych nie powoduje zniesienia obowiązku uiszczania podatku kościelnego ${ }^{19}$.

\section{Wyjaśnienie Konferencji Episkopatu RFN z 24.04.2006 r. w sprawie wystąpienia z Kościoła katolickiego}

Jak już wyżej wspomniano, opublikowanie Listu okólnego Papieskiej Rady do Spraw Tekstów Prawnych z 13 marca 2006 roku, określającego szczegółowo sposób wystąpienia z Kościoła, spowodowało powstanie wielu wątpliwości w Niemczech, i to zarówno ze strony państwowej, jak i kościelnej ${ }^{20}$. Wówczas to Konferencja Episkopatu Niemiec, w dniu 24 kwietnia 2006 roku wydała „Wyjaśnienie” (Erklärung) na temat wystąpienia z Kościoła katolickiego w Niemczech ${ }^{21}$, w którym stwierdziła, iż List okólny Papieskiej Rady nie naruszył porządku prawnego istniejącego w Niemczech w sprawie wystąpienie z Kościoła katolickiego. Jednocześnie wyjaśniono, że Kirchernaustritt zdeklarowany wobec władzy państwowej jest formalnym odejściem od Kościoła katolickiego, i dlatego stanowi przestępstwo równoznaczne ze schizmą (w rozumieniu kan. $751 \mathrm{KPK}$ ), za które przewidziana jest kara ekskomuniki latae sententiae (kan. 1364 §1 KPK) ${ }^{22}$. Nadmieniono również, że po złożeniu deklaracji o wystąpieniu z Kościoła wobec władz państwowych, i przesłaniu przez nie informacji do odpowiedniego urzędu kościelnego, akt wystąpienia z Kościoła staje się ważny również na forum kościelnym, a wspomnianą informację zapisuje się na marginesie aktu chrztu zainteresowanego. Dodano, że oceny aktu wystąpienia $\mathrm{z}$ Kościoła nie zmieniają motywy czysto finansowe, chodzi bowiem o odmowę solidarnego wspierania Kościoła i zaradzania jego potrzebom, do czego zobowiązani są wszyscy wierni w kann. 222 §1 i 1262 KPK. Przypomniano wreszcie skutki

\footnotetext{
${ }^{19}$ R. PuzA, Le conseguenze civili, s. 33.

${ }^{20}$ Zob. R. PuzA, Les sorties de l'Eglise. La situation Allemande (Kirchenaustritt), L'Anné Canonique 48(2006), s. 19-133.

${ }^{21}$ Erklärung der Deutschen Bischofskonferenz zum Austritt aus der katholische Kirche (24.04.2006), http://nomokanon.de/quellen/031.htm; Zob. także B. BANACH, Wystapienie z Kościoła katolickiego, http://wystaw.pl/jeszcze-o-kirchernaustritt.

${ }^{22}$ Wyjątkowo w Bremie Kirchenaustritt składa się przed władzą kościelną.
} 
ekskomuniki. Jednocześnie duszpasterze zostali zobowiązani do podjęcia wszelkich wysiłków umożliwiających osobie, która wystąpiła z Kościoła, powrót do tej wspólnoty ${ }^{23}$.

„Wyjaśnienie” biskupów niemieckich nie uchyliło całkowicie wątpliwości co do stosowności formy wystąpienia z Kościoła, m.in. odnośnie do możliwości tzw. zmodyfikowanego oświadczenia o wystąpieniu z Kościoła (modifizierten Kirchenaustritt). Forma ta polegała na tym, że poza deklaracją woli wystąpienia z Kościoła jako korporacji prawa publicznego, dana osoba składa jednocześnie oświadczenie, iż pragnie pozostawać wyznawcą tegoż Kościoła jako wspólnoty religijnej. W znanym przypadku prof. Hartmuta Zappa, który w lipcu 2007 roku wystąpił z Kościoła katolickiego na mocy formalnej deklaracji złożonej w Urzędzie Stanu Cywilnego, aby nie płacić obowiązkowego podatku kościelnego, a następnie prosił o dopisanie, że występuje z Kościoła wyłącznie jako korporacji prawa publicznego, a nie ze wspólnoty religijnej, po uznaniu racji kanonisty z Fryburga Bryzgowijskiego przez lokalny Sąd Administracyjny i po złożeniu rekursu przez archidiecezję fryburską, Sąd Apelacyjny Badenii-Wittenbergii orzekł w 2010 roku, iż deklaracji zmodyfikowanej nie można uznać za ważną, co - po odwołaniu się zainteresowanego - potwierdził w wyroku z 26 września 2012 roku Federalny Sąd Administracyjny w Lipsku, unieważniając deklarację Zappa. $\mathrm{W}$ orzeczeniu tym stwierdzono także, że sprawę przynależności do danej wspólnoty religijnej reguluje jej prawo wewnętrzne, lecz żaden jej członek nie może być wyjęty od obowiązków, które ta przynależność niesie ze sobą ${ }^{24}$.

\section{Dekret generalny Konferencji Episkopatu RFN z 20.09.2012 r. w sprawie wystąpienia $\mathrm{z}$ Kościoła katolickiego}

$\mathrm{W}$ trakcie trwania procedury odwoławczej w sprawie deklaracji zmodyfikowanej H. Zappa, to jest w marcu 2011 roku, Konferencja

\footnotetext{
${ }^{23}$ B. BANACH, Wystapienie, s. 3.

${ }^{24}$ P. V. Simone Braida, Breve commento, s. 482-485; R. Puza, Le conseguenze civili, s. 30-31.
} 
Episkopatu Niemiec przyjęła Dekret generalny dotyczący wystąpienia z Kościoła, który - po otrzymaniu recognitio Stolicy Apostolskiej został opublikowany 20 września $2012 \mathrm{roku}^{25}$. W dokumencie tym, wydanym po zniesieniu przez m.p. Benedykta XVI Omnium in mentem z 26 października 2009 roku klauzuli o wystąpieniu z Kościoła formalnym aktem, przedstawiono w sposób szczegółowy i pogłębiony całą problematykę związaną z wystąpieniem z Kościoła.

W pierwszej części Dekretu przypomniano pokrótce historię Kirchensteuer (XIX wiek) oraz określono charakter oświadczenia o wystąpieniu z Kościoła składanego przed właściwym urzędem cywilnym („zamierzone i świadome zdystansowanie się od Kościoła, uznawane za poważne uchybienie wobec wspólnoty Kościoła” - kan. $209 \S 1 \mathrm{KPK}$ oraz „naruszenie obowiązku finansowego wspierania Kościoła" - kann. 222 §1 i 1263 KPK).

W drugiej części dokumentu biskupi niemieccy wskazują na konsekwencje prawne oświadczenia o wystąpienia z Kościoła: 1 . zakaz przyjmowania sakramentów: pokuty, Eucharystii, bierzmowania i namaszczenia chorych - z wyjątkiem sytuacji niebezpieczeństwa śmierci; piastowania stanowisk kościelnych i pełnienia funkcji w Kościele; pełnienia roli chrzestnego i świadka bierzmowania; przynależenia do rad parafialnych i diecezjalnych (rada parafialna, zarząd parafialny, rada ds. zarządu majątkiem, diecezjalna rada duszpasterska); czynnego i biernego prawa wyborczego obowiązującego w Kościele; przynależenia do publicznych stowarzyszeń kościelnych (kan. 316 KPK); 2. konieczność uzyskania zezwolenia ordynariusza miejsca na zawarcie małżeństwa (po złożeniu przyrzeczenia o zachowaniu wiary i katolickim wychowaniu dzieci - kann. 1071 i 1125 KPK); 3. odmowa pogrzebu kościelnego, chyba że dana osoba okazała przed śmiercią jakiekolwiek oznaki pokuty (kan. 1184 §1, n. 3 KPK);

\footnotetext{
${ }^{25}$ Allgemeines Dekret der Deutschen Bischofskonferenz zum Kirchenaustritt, https:// www.gogle.p./\# q = allgemeines+dekret+der+deutschen=bischofskonferenz; Zob. S. Haering, Die neue gesetzliche Ordnung der Deuschen Bischofskonferenz zum Austritt der katholischen Kirche vor der staatlichen Behörde, Klerusblatt 92(2012), s. 249-257.
} 
4. w przypadku wykonywania przez daną osobę posługi kościelnej obowiązują konsekwencje przewidziane we właściwej ustawie kościelnej (art. 3 ust. 4 Podstawowego regulaminu dotyczącego posługi kościelnej w ramach kościelnych stosunków pracy: „Ten, kto jest wrogo nastawiony do Kościoła lub wystąpił z Kościoła, nie nadaje się do sprawowania żadnych funkcji w Kościele" - Biskupi niemieccy 2008); 5. w przypadku pełnienia przez daną osobę określonej funkcji kościelnej na podstawie udzielonego jej upoważnienia kościelnego (misio canonica dla nauczycieli religii i nihil obstat dla profesorów teologii), należy takie upoważnienie cofnąć.

W punkcie 6 , o charakterze specjalnym, biskupi stwierdzają, iż władza kościelna zaprasza osoby, które złożyły oświadczenie o wystąpieniu z Kościoła, na rozmowę dotyczącą ich ponownego przyłączenia do wspólnoty kościelnej. Rozmowa ta ma na celu pojednanie z Kościołem i powrót do pełnego wykonywania praw i obowiązków. Jeśli reakcja wiernego, który zadeklarował chęć wystąpienia z Kościoła, wskazuje na akt schizmatycki, heretycki lub apostatyczny, ordynariusz ma zadbać o to, by zostały podjęte właściwe kroki. Pismo, które należy wysłać do osoby występującej z Kościoła (bezpośrednio po otrzymaniu informacji na temat wystąpienia z Kościoła - według załącznika), a także rozmowa, o której mowa, nie mają skutku zawieszającego.

W dokumencie dodano, że we wszystkich krajach związkowych (landy), za wyjątkiem Bremy, wystąpienie z Kościoła ma miejsce przed urzędem cywilnym, w Bremie zaś - przed instytucją kościelną.

Jak nietrudno zauważyć, w Dekrecie generalnym - odmiennie niż w „Wyjaśnieniu” z 24 kwietnia 2006 roku - w żadnym punkcie nie wspomina się o ekskomunice. Jak zauważa V. A. Braida, niewątpliwie wzięto tutaj pod uwagę dyspozycje Listu okólnego Papieskiej Rady do Spraw Tekstów Prawnych z 13 marca 2006 roku. Nic też dziwnego, że w części drugiej punktu szóstego Dekretu generalnego, po wzmiance o zaproszeniu przez władzę kościelną osoby, która złożyła deklarację Kirchenaustritt, do rozmowy - w perspektywie powrotu tej osoby do wspólnoty kościelnej i odzyskania w niej wykonywania pełnych praw i obowiązków - dodaje się, że ilekroć z reakcji wiernego wynika, że 
chodzi o akt schizmy, herezji lub apostazji, ordynariusz obowiązany jest do podjęcia odpowiednich środków. Nie ma tutaj mowy wprost o ekskomunice, lecz w istocie została ona implicite przywołana, skoro w przypadku apostazji, herezji i schizmy „odpowiednimi środkami” są sankcje przewidziane w kan. $1364 \mathrm{KPK}$, a więc ekskomunika latae sententiae ${ }^{26}$. Ordynariusz miejsca powinien wówczas zdeklarować - w trybie kan. $1342 \S 1 \mathrm{KPK}$ - zaciągnięcie przez wiernego wymienionej kary.

Pewną trudność może nasuwać sytuacja, w której osoba, która złożyła przed władzą świecką deklarację o wystąpieniu z Kościoła katolickiego, lecz nie odpowiedziała na zaproszenie władzy kościelnej na rozmowę, o której w punkcie 6 Dekretu generalnego. Trudno wówczas ocenić racje wystąpienia takiej osoby z Kościoła, wszak wystąpienie to, zdeklarowane jedynie wobec władzy państwowej, nie może być uznane jako akt herezji, schizmy czy apostazji. W świetle drugiej części Dekretu generalnego należy zatem przyjąć, iż wierny taki nie zaciągnął ekskomuniki (wiążą go jednak wszystkie sankcje wymienione w punktach 1-5 Dekretu generalnego ${ }^{27}$.

Inną trudność stwarza przypadek katolików-imigrantów w Niemczech (przybywających tu m.in. z Italii), którzy zdeklarowali przed niemieckimi władzami państwowymi swoje wystąpienie z Kościoła jedynie dla oszczędności podatkowej i nie stawili się na rozmowę z proboszczem. Wątpliwość dotyczy tego, czy sankcje Dekretu generalnego wymienione w punktach 1-5 (drugiej części) wiążą ich tylko na terenie Niemiec, czy także w całym Kościele, a więc również kraju, z którego przybyli. Podczas gdy kanoniści włoscy odpowiadają, że

\footnotetext{
${ }^{26}$ P. V. Simone BRAida, Breve commento, s. 491.

${ }^{27}$ Przeciwko uznawaniu na forum kościelnym skutków Kirchenaustritt zdeklarowanego przed władzami państwowymi wypowiedzieli się m.in.: E. Corecco (Dimettersi dalla Chiesa per ragioni fiscali, w: Jus et Communio. Scritti di Diritto Canonico, red. G. Borgonovo e A. Cattaneo, t. 1, Lugano 1997, s. 387-429) i V. DE PAOLIs (Alcune annotazioni circa la formula ,, actu formali ab Ecclesia catholica deficere", Periodica 84/1995/, s. 579-608). Według nich, z punktu widzenia prawnego wystąpienie z Kościoła z motywów fiskalnych nie może być zakwalifikowane jako herezja, schizma lub apostazja. Zob. M. KoseK, Podatek kościelny, s. 127-140.
} 
sankcje te są skuteczne wyłącznie na terytorium Niemiec, to ordynariusze niemieccy, którzy powiadamiają odnośne kurie biskupie miejsca zamieszkania tych wiernych w Italii o złożeniu przez nich deklaracji Kirchenaustritt, wyrażają zdziwienie z powodu nierespektowania takich powiadomieńn ${ }^{28}$.

\section{Pismo pastoralne (załącznik do Dekretu generalnego)}

Do Dekretu generalnego Konferencji Episkopatu Niemiec został dołączony wzór Pisma pastoralnego (Pastorales Schreiben) ${ }^{29}$, które proboszcz powinien skierować do wiernego, który przed właściwym urzędem cywilnym złożył oświadczenie o wystąpieniu z Kościoła katolickiego. W piśmie tym proboszcz informuje adresata o tym, że z przykrością przyjął informację o jego wystąpieniu z Kościoła katolickiego, wyrażając jednocześnie pragnienie odbycia z nim rozmowy na temat przyczyn, które skłoniły go do podjęcia takiego kroku oraz w celu dokonania właściwej oceny sytuacji. Proboszcz uświadamia następnie zainteresowanemu, że ochrzczeni w Kościele katolickim lub do niego przyjęci sprawują swoje posłannictwo właściwe ludowi chrześcijańskiemu w Kościele i w świecie (Lumen gentium, n. 31) i cieszą się wszystkimi podstawowymi prawami dotyczącymi aktywnego udziału w życiu kościelnym, co jednak ściśle uwarunkowane jest wypełnianiem obowiązków we wspólnocie kościelnej.

W dalszym ciągu swojego pisma proboszcz zaznacza, że - z polecenia biskupa - ma pouczyć wiernego o znaczeniu, jakie ma wystąpienie z Kościoła, i o konsekwencjach kościelno-prawnych takiego aktu. Informuje go więc, iż oświadczenie o wystąpieniu z Kościoła składane przed właściwym urzędem cywilnym stanowi - jako akt jawny - zamierzone i świadome zdystansowanie się od Kościoła i jest uznawane za poważne uchybienie wobec wspólnoty Kościoła; jest naruszeniem obowiązku troski o zachowanie wspólnoty z Kościołem (kan. 209 §1 KPK) i obowiązku finansowego wspierania Kościoła, jako czegoś niezbędnego do wypełniania przezeń własnych zadań

\footnotetext{
${ }^{28}$ P. V. Simone Braida, Breve commento, s. 492.

${ }^{29} \mathrm{http}: / /$ www.dbk.de/fileadmin/redaktion/diverse_downloads/pr.
} 
(kann. 222 §1 i 1263 KPK). Proboszcz wskazuje następnie adresatowi swego pisma skutki prawne oświadczenia o wystąpieniu z Kościoła (wymienione w punktach 1-3 drugiej części Dekretu generalnego).

W zakończeniu pisma jego autor zaprasza wiernego na rozmowę z nim (lub z innym dowolnie wybranym duszpasterzem), aby wyjaśnić zaistniałą sytuację. Zaznacza jednocześnie, że nawet jeśli adresat nie myśli o zmianie swojej decyzji, to jednak proszony jest o odpowiedź.

W dniu 21 stycznia 2013 roku Rada Stała Konferencji Episkopatu Niemiec opublikowała zmodyfikowany wzór alternatywnego Pisma pastoralnego proboszcza (kierowanego po otrzymaniu wiadomości o złożeniu przez wiernego oświadczenia o wystąpieniu z Kościoła katolickiego), wskazując komponenty - stałe i do wyboru - tegoż Pastorales Schreiben ${ }^{30}$.

Opcje do wyboru odnoszą się do wstępnej części pisma i dotyczą dwóch sytuacji: gdy osoba występująca z Kościoła jest proboszczowi znana, i gdy nie jest mu osobiście znana. Jeśli dana osoba jest nu znana, zaznacza to w piśmie; jeśli jest nieznana, wyraża żal, że nie udało mu się z nią wcześniej porozmawiać.

Stały element Pisma pastoralnego obejmuje zwrócenie się do adresata $\mathrm{z}$ serdecznym zaproszeniem go do rozmowy na temat motywów zerwania więzów ze wspólnotą Kościoła, a także na temat wiary, Kościoła, Ewangelii i życia. Jednocześnie proboszcz ma zaznaczyć, że kieruje swój list w imieniu biskupa diecezji (podaje jego nazwisko i siedzibę biskupstwa) dodając, że biskupi zadecydowali, by na tej drodze raz jeszcze podjąć próbę kontaktu z osobą występującą z Kościoła. Ma też nadmienić, że w przypadku pytań adresata może (jako proboszcz) skierować do niego kompetentną osobę.

Następnie proboszcz stwierdza, że problem opuszczenia wspólnoty kościelnej nie dotyczy utraty wpływów z podatku kościelnego, choć pomoc taka potrzebna jest Kościołowi do realizacji własnych celów. Nadmienia też, że przez publiczne oświadczenie o wystąpieniu z Kościoła wierny świadomie dystansuje się od tej wspólnoty, co może być formą skrajnej krytyki tegoż Kościoła lub wyrazem

\footnotetext{
${ }^{30}$ Tamże.
} 
poważnego gniewu czy też trwającego od dłuższego czasu oddalenia się od Kościoła. Wyjaśnia też, iż Kościół jest nie tylko organizacją, lecz także rzeczywistością duchową, a obydwa te aspekty są nierozdzielnie ze sobą związane, jak to podkreśla Konstytucja soborowa Gaudium et spes (przytacza się tutaj odnośny fragment n. 8); nadmienia, iż pomimo wad istniejących w Kościele, które mają swój początek w ludziach, istnieją niewątpliwe powody do pozostawania w tej wspólnocie.

W Piśmie pastoralnym proboszcz informuje następnie swojego adresata, że zdecydowane zerwanie więzów z Kościołem poprzez oświadczenie o wystąpieniu z niego, niesie ze sobą konkretne i fundamentalne konsekwencje, które z powagą trzeba potraktować, i to także wówczas, gdy osoba występująca z Kościoła nie jest ich do końca świadoma. Z kolei proboszcz wskazuje na owe konsekwencje przytaczając sankcje wymienione w punktach 1-3 drugiej części Dekretu generalnego.

$\mathrm{W}$ ostatnim akapicie pisma jego autor prosi wiernego o zrozumienie, iż przedstawił mu konsekwencje jego oświadczenia o wystąpieniu z Kościoła w tak dobitny sposób, chodzi jednak o poważne potraktowanie takiej decyzji o zerwaniu więzów ze wspólnotą kościelną. Informuje adresata listu także o możliwości ponownego zbliżenia się do Kościoła i wstąpienia na drogę prowadzącą znów ku wspólnocie. W ostatnim zdaniu stwierdza, że także po podtrzymaniu decyzji o wystąpieniu z Kościoła adresat listu nie będzie mu obojętny, co ma mu uświadomić właśnie ten list.

W zakończeniu pisma proboszcz ponownie zaprasza wiernego na rozmowę i zaznacza, że może to nastąpić nawet w terminie późniejszym. Wyraża mu następnie podziękowanie za dotychczasowy wkład w życie Kościoła oraz zapewnienia o modlitwie o Boże błogosławieństwo dla niego i jego bliskich (jeśli proboszcz nie zna osobiście adresata listu, treść zakończenia może zmodyfikować).

\section{Zakończenie}

Wprowadzając w kann. 1086 §1, 1117 i 1124 KPK klauzulę o formalnym wystąpieniu z Kościoła katolickiego, a tym samym uchylając 
obowiązującą dotąd zasadę semel catholicus, semper catholicus (kan. $11 \mathrm{KPK}$ ), ustawodawca chciał przede wszystkim zagwarantować ważność małżeństw osób, które dokonały takiego odstępstwa (wyjęcie ich spod obowiązku zachowania formy kanonicznej miało ułatwić im wykonywanie ius connubii). Mimo wszystko, decyzja ta okazała się niefortunna.

Zgłaszane coraz częściej wątpliwości dotyczące rozumienia kodeksowego zwrotu actus formalis defectionis ab Ecclesia catholica skłoniły Papieską Radę do Spraw Tekstów Prawnych do udzielenia obszernych wyjaśnień na ten temat w Liście okólnym z 13 marca 2006 roku. Czymś szczególnie znaczącym było tu stwierdzenie, iż formalny akt odstąpienia od Kościoła katolickiego (obejmujący decyzję wewnętrzną, jej ujawnienie władzy kościelnej oraz przyjęcie jej przez tę władzę), mający wszystkie znamiona ważnego aktu prawnego, nie ma jedynie charakteru prawno-administracyjnego, lecz także wymiar teologiczny, zakłada bowiem dokonanie aktu apostazji, herezji lub schizmy. Aktu takiego nie mogło zatem stanowić zwykłe „wypisanie się" z rejestru członków wspólnoty kościelnej, m.in. poprzez złożenie na ręce władz państwowych oświadczenia o nieuiszczaniu podatku kościelnego. Wielu przedstawicieli doktryny kanonistycznej upatrywało właśnie w Liście okólnym odpowiedź na problem, jaki powstał w Niemczech w odniesieniu do skuteczności na forum kościelnym wystąpienia z Kościoła tamtejszych katolików, którzy odmawiali płacenia podatku na Kościół i składali w tym celu - przed podatkowym urzędnikiem cywilnym - deklarację o wystąpieniu z Kościoła katolickiego.

Wydane 24 kwietnia 2006 roku przez Konferencję Episkopatu Niemiec „Wyjaśnienie” na temat wystąpienia z Kościoła katolickiego, zawierające stwierdzenie, iż List okólny Papieskiej Rady nie naruszył porządku prawnego obowiązującego w Niemczech w sprawie wystąpienie z Kościoła katolickiego, oznaczało, iż jedynym sposobem formalnego wystąpienia $\mathrm{z}$ Kościoła katolickiego $\mathrm{w}$ tym kraju jest nadal Kirchernaustritt zdeklarowany wobec władzy państwowej, stanowiący przestępstwo równoznaczne ze schizmą, za które przewidziana jest kara ekskomuniki latae sententiae. 
Całkowicie słuszne uchylenie przez motu proprio Benedykta XVI Omnium in mentem z 26 października 2009 roku klauzuli kodeksowej nie miało większego znaczenia dla status quo porządku prawnego obowiązującego w Republice Federalnej Niemiec, gdzie odejście od Kościoła katolickiego ma swój szczególny charakter i oryginalną regulację (w poszczególnych landach), a która wynika $z$ historycznego powiązania przynależności wyznaniowej do Kościoła z obowiązkiem uiszczania podatku kościelnego.

Za znaczący należy uznać ogłoszony 20 września 2012 roku przez Konferencję Episkopatu Niemiec Dekret generalny, w którym przedstawiono w sposób szczegółowy i pogłębiony całą problematykę związaną z wystąpieniem z Kościoła. Istotnym novum dokumentu było pominięcie wzmianki o karze ekskomuniki (zdeklarowanie jej zaciągnięcia uzależniono od oceny aktu Kirchenaustritt: czy ma on znamiona aktu schizmy, herezji lub apostazji). Pozytywnie należy ocenić także wypracowany przez biskupów niemieckich wzór Pisma pastoralnego (Pastorales Schreiben).

Podatek kościelny w Niemczech, będący instytucją państwową, stanowiący integralny element niemieckiego systemu relacji państwo - Kościól, mający swoje uwarunkowania historyczne oraz umocowanie konstytucyjne, wpisujący się w pewien sposób w mentalność niemiecką, może budzić zastrzeżenia. Przede wszystkim dyskusyjny pozostaje problem oceny na gruncie prawa kościelnego oświadczenia o wystąpieniu z Kościoła jako jedynego sposobu uwolnienia się od podatku kościelnego. Trudność tej oceny wynika $\mathrm{z}$ faktu, że przyjęte w ustawodawstwie niemieckim rozwiązanie sugeruje, że obowiązek świadczeń materialnych na rzecz Kościoła jest w sposób istotny powiązany z samą przynależnością do tej wspólnoty. Rozwiązanie można kwestionować w szczególności w perspektywie teologicznej, jakkolwiek bowiem świadczenie materialne na rzecz Kościoła - stosownie do kann. 222 §1 i $1262 \mathrm{KPK}$ - jest ważnym obowiązkiem (notoryczne zaniedbywanie go może rodzić określone konsekwencje także na gruncie prawa kościelnego), to jednak jego spełnianie nie może warunkować samej przynależności do Kościoła, co właśnie wprowadza system niemiecki. 
Należy jednak pamiętać o tym, że każdy Kościół lokalny posiada swoje własne cechy (pewien „profil”), które sprawiają, że jego określony system finansowania - jeśli nie stoi w sprzeczności z kościelnym prawem powszechnym - może zyskać akceptację.

\section{The problem of defection from the Catholic Church in the German Federal Republic}

The introduction of a clause of formal act of defection from the Catholic Church to Code of Canon Law, explained by the Pontifical Council for Legislative Texts in 2006 and then abolished by pope Benedict XVI in 2009, was of no significance for the legal regulation in force in German Federal Republic. As a result of historical circumstances existing in this country, the only way to formally defect from the Catholic Church is still Kirchenaustritt declared at a state authority, which is - as stated in 2006 by the country's Episcopal Conference of German Federal Republic - a crime tantamount to schism, for which the prescribed penalty is excommunication latae sententiae. However, an essential novum occurred in the General Decree of Episcopal Conference of German Federal Republic from 2012: the mention of excommunication was omitted (declaring its incurrence became dependent on the assessment of the act Kirchenaustritt: whether it constituted an act of schism, heresy or apostasy). This modification should be regarded as positive, just like Pastoral Letter (Pastorales Schreiben) developed by the German Bishops and attached to the General Decree.

It is necessary to emphasize that the problem of assessment - on canon law basis - of statement of defection from the Catholic Church as the only way to exempt from the church tax, is still open to dispute (inter alia german milieu).

SŁowA Kluczowe: wystąpienie z Kościoła katolickiego formalnym aktem, podatek kościelny

KEY Words: a formal act of defection from the Catholic Church, Church tax

\section{Nota o Autorze:}

Ks. PROF. ZW. DR HAB. WOJCIECH GóRALSKI - pracownik naukowo-dydaktyczny na Wydziale Prawa Kanonicznego Uniwersytetu Kardynała 
Stefana Wyszyńskiego w Warszawie, założyciel i redaktor naczelny rocznika, a następnie kwartalnika „Ius Matrimoniale”, wiceprzewodniczący Stowarzyszenia Kanonistów Polskich, członek Consociatio Internationalis Studio Iuris Canonici Promovendo, konsultator Trybunału Roty Rzymskiej, członek Komitetu Nauk Prawnych PAN, autor licznych prac z zakresu kanonicznego prawa małżeńskiego, historii prawa kanonicznego i prawa wyznaniowego. 